\title{
Observations on Poets and Poetry
}

\author{
THOMASO. MABBOT T
}

\section{Introductory}

The Thomas Ollive Mabbott Collection at The University of Iowa covers adequately the recorded Mabbott interests and accomplishments. One may see there his work on Milton, Whitman, and Pinkney, and his more extensive work on Poe, including Volumes I, II, and III of the Mabbott edition of the Collected Works of Edgar Allan Poe (Belknap Press, Harvard University Press, 1969, 1978). The shelves contain copies of his articles on minor figures in English and American literature, and a file of the Numismatic Review he edited, as well as copies of the sale catalogues of his coin collection. They do not, however, exhibit anything of what was perhaps the most important of all the Mabbott accomplishments. Classroom teaching, like acting on the stage, leaves few written records; and T. O. M., who often referred to himself as a failed actor, was, as students testify, an inspired teacher.

As it happens, the collection does contain, in a series of letters and notes not yet open to the public, a small sample of the Mabbott way with poets and poetry. Most of these letters were written in 1923 and 1924 when he was a new Ph.D. in charge of one of the sections in the Master's Program at Columbia University. The recipient was a senior at the University of Chicago, majoring in English literature and obviously reporting on poets studied at the time. ${ }^{1}$ Some of the passages that follow are combinations of isolated statements, and the whole is arranged so that the general statements precede the more particular observations. Time and experience changed T. O. M.'s emphasis on some of the individual poets, but only deepened his commitment to poets and poetry. The following excerpts from these letters reveal an aptitude, shall we say, for the teaching of undergraduates he was shortly to begin.

1 The letters were written to Maureen Cobb, afterwards Mrs. Mabbott, who has made the selection of excerpts for the present essay. 


\section{Divisions of Poetry, and Standards}

There are four divisions of English poetry-supreme, notable, significant for an age, significant for a scholar. A man may go from the third to the fourth. Shakespeare, Homer, and Whitman belong to the first. The reader who does not read Greek will probably conclude that Shakespeare is the greatest because Homer becomes tiresome in translation. But then, I must go on to say, no one can criticize poetry who has not read the greatest poetry, the Greek, in the original.

Although my chief scholarly work has been on an American poet, I feel like making a clear-cut assertion that there is not a distinct literature apart from that of England. It is my belief that the most profitable study can now be only of the intertwined and inseparable literatures of the world.

I do not insist that one admire every kind of poetry, but I do protest against those who set up personal standards to which they think a poet must conform, unless it be a standard to which such varied things as the Labuntur anni of Horace, the best of the Spoon River Anthology, the "Resolution and Independence" of Wordsworth, and Pope's Epistle to Dr. Arbuthnot obviously do conform.

I have heard a lot about the essential difference between the poetry of Poe and Coleridge, but I have never been able to see any difference that I thought essential. In fact, I am sure that what they have in common is what counts, and that is the essentially poetic quality. It is not only that I think "Kubla Khan," "The Eve of St. Mark" by Keats, and Pope's "Elegy to the Memory of an Unfortunate Lady" great poems-I think they have the same quality of greatness, and differ only in manner, which is not essential.

\section{Textbooks}

The only composition textbook I would have is Robert Henri's The Art Spirit. ${ }^{2}$ This artist and teacher in his book presents revelations and directions for the students of art that are wise and useful for all teachers and students. The instructor who can say as he does that "our future freedom rests in the hands of those whose likeness will be in their dissimilarity" will not penalize a student for disagreeing with him, nor give the highest marks to those who parrot his observations. And I do so much agree with his initial statement: "Art when really understood is the province of every human being."

2 Robert Henri, The Art Spirit: Notes, Articles, Fragments of Letters and Talks to Students, Bearing on the Concept and Technique of Picture Making, the Study of Art Generally, and on Appreciation, compiled by Margery Ryerson (Philadelphia: J. B. Lippincott Company, 1923 and later editions). 
In an edition of Beowulf I would have a picture of the Frank's casket-perhaps only that, but surely that. College professors are too quick to scom pictures, coins, maps, all the means by which we put ourselves into any period. Brander Matthews could give you the spirit of the Elizabethans by some such statement as this: "The people of Shakespeare's time liked to see eyes put out on the stage." It wasn't that he knew so much about a period, but that he could grasp such marks of identification quickly. Of course, in all the process of learning and teaching one never knows what the vital thing will be. A story in Little Men influenced mel There was a boy in it who did not like flowers and so he had a weed garden. I remember thinking that, if he wanted to be a scientist, he'd have to study the weeds.

\section{Thomas a Kempis}

I have been reading the Imitation of Christ, that is the opening chapters, and find myself much illuminated by the constant use of the text, "the ear is not satisfied with hearing, nor the eye with seeing"-it explains so much that I have long felt, and yet I cannot wholly feel that the best solution is an absolute renunciation of the world, which the author advocates. Yet it is one solution and if he is too ascetic for you (as you once wrote me) and for me, I don't think he was too ascetic for Thomas a Kempis. "We shall be asked what we have done, not what we have read,"-another text for the scholar to keep before him constantly!

\section{William Dunbar}

Dunbar's "To the Princess Margaret" is itself didactic, for what it teaches is the harmony of the universe which we learn best from such things. To know the line "Born of a princess most serene" is to have a reason for living:

Younge tender plant of pulcritud,

Descendyd of Imperyalle blude;

Freshe fragrant floure of fayrehede shene,

Welcum of Scotland to be Quene!

Sweet lusty lusum lady clere,

Most mighty kyngis dochter dere,

Born of a princess most serene, Welcum of Scotland to be Quene! 


\section{Christopher Marlowe}

Marlowe is, besides Shakespeare, the only absolutely first-rate genius among the Elizabethans, though they numbered so many almost firstrate writers that one hates to say that. Yet in his own field-the poetry of the most completely exuberant passion-nobody, not even Sappho or Catullus, or Shakespeare in Romeo and Juliet, has surpassed the speech of Faustus to Helen, she "who launched a thousand ships" and was

fairer than the evening air

Clad in the beauty of a thousand stars;

nor has Vergil more dignified and magnificent lines than those in Mephistopheles' address on the whereabouts of Hell:

Hell hath no limits, nor is circumscrib'd

In one self place; for where we are is hell,

And where hell is, there must we ever be:

And to conclude, when all the world dissolves,

And every creature shall be purified,

All places shall be hell that are not heaven.

\section{Shakespeare}

Have you read Coriolanus? That is a marvelous, sombre, proud, understanding play, and alone would prove W. S.'s importance to a really discerning critic, I think. Neglect of Coriolanus puzzles me. I fear nowadays few people read even Shakespeare through.

As for the sonnets-there are no nightingales here. They are the fire of love, not merely the blaze of passion but the "flame within" Catullus mentions. Surely I have hitherto underrated the sonnets, partly because I am impatient of conceits, the straining for contrasting parallels which the Elizabethans so desired. But this defect of manner is of the age, not the man. The magnificent boldness of sonnet 35 , line 2 , "Roses have thorns and silver fountains mud," shows the master's hand. How we strive to be familiar in our verse and prove only lowwhile Shakespeare forgives the mud for the silver shine of the watersand perhaps makes us feel a little the inextricable winding together of all the objects of reality.

\section{John Donne}

As for Donne, your comment that you enjoyed his work, when you put your mind to it, is only at first glance a condemnation of his poeti- 
cal powers. The conceits, the subtleties, and indeed everything characteristic of what Dr. Johnson called the metaphysical school is, I think, rather at war with true poetry-and with Donne, remember that he is a very uneven poet. But the interest taken in a writer should be apart from his excellence or lack of it in producing the poetic sentiment in his readers, and the exhibition of the human mind searching out strange thoughts is an interesting one. Treating Donne as a thinker might prove easier than anything else. But I suppose you have a subject on Donne! To be quite honest I think it is fortunate that I never had to write any literary papers, as nothing save source work and bits of criticism which are in themselves works of art, made a very definite appeal to me-except in the recognition of what Poe terms "supernal beauty." You will like Donne's

\author{
Song \\ Sweetest love, I do not go \\ For weariness of thee, \\ Nor in the hope the world can show \\ A fitter love for me; \\ But since that I \\ Must die at last, 'tis best \\ To use myself in jest \\ Thus by feign'd deaths to die. \\ Yesternight the sun went hence, \\ And yet is here today: \\ He hath no desire nor sense, \\ Nor half so short a way. \\ Then fear not me, \\ But believe that I shall make \\ Speedier journeys, since I take \\ More wings and spurs than he.
}

\title{
Robert Herrick
}

Herrick's best work is somewhat akin to the best of Ben Jonson and has some of the Elizabethan flavor-his worst, again like Ben's work, is a mere imitation of Martial, to whom I believe he is much indebted. I should rate him below Landor, whose sympathy with the Greeks was closer probably. Thomas Bailey Aldrich was a great admirer of the poet, and one should consider his finer lyrics and epigrams apart from the unattractive side of the man, in the belief that his occasional 
coarseness was due in part to the surviving medieval grotesque element of Elizabethan culture, in part to the false taste for classical obscenities which Ben Jonson did too much to encourage, and which may accompany very genuine piety. Herrick has a special place in my personal anthology because "The Night-Piece: To Julia" was the first poem I ever appreciated as a poem. Look at the first two stanzas here; I will picture you reading the last two in your book and thus we read it together:

Her eyes the glow-worm lend thee,

The shooting stars attend thee;

And the elves also,

Whose little eyes glow

Like the sparks of fire befriend thee.

No Will-o'the-Wisp mislight thee,

No snake or slow-worm bite thee;

But on, on thy way

Not making a stay,

Since ghost there's none to affright thee.

\section{John Milton}

Your reading in Milton must be turning your mind to the problem of the origin of evil, which is so fundamental that it can never be fully grasped by the human mind, but of course his making Satan the hero from the tragic point of view was just as necessary as for Shakespeare to heroize Macbeth. Aeneas is a hero in this sense, and Vergil made his hero a model from some points of view, which Milton never intended with Satan. Blake's symbolism, I think, called energy "satanic." In old age he said that he had seen the real devil and drew a most shocking picture of him with which Milton's Satan had little in common. Among the things that stand out in Paradise Lost is

Among the faithless, faithful only he.

That line has the greatest of all the Miltonic cadences and the glorious connotation-the one angel who was not seduced, his courage, the hatred his faithfulness must arouse among the rebels stand out from all the poem in my memory. And is there anything more perfect than the last lines of Comus: 
Mortals that would follow me,

Love Virtue; she alone is free.

She can teach ye how to climb

Higher than the sphery chime;

Or, if Virtue feeble were,

Heaven itself would stoop to her.

\section{Thomas Chatterton}

You do guess right about Thomas Chatterton-there is a certain sympathy with him. But also there is a quite impersonal respect. Shakespeare, Milton, Byron-so I rank them in order, but Chatterton, had he accomplished his promise, would have been among them and perhaps third rather than fourth. Of course that is a purely personal ranking-but the admiration is just, I think. A survey of T. C. biographers will show you much of the incompetence of learned men!

As you know I regard the Bristol boy as a very important poetthe only person to whom I would apply the word Shakespearean, and I have a very great regard for his work, which is neglected by the criticasters of this country sadly. Only the last of Comus is greater than the final stanza of

\section{A Balade of Charitie}

But ah! unhappy pilgrim, learn of me, Scarce any give a rentroll to their lord; Here, take my semicope, thou'rt bare, I see.

Tis thine; the saints will give me my reward.

He left the pilgrim, and his way aborde.

Virgin and holy Saints, who sit in gloure [glory]

Or give the mighty will, or give the good man power!

\section{John Dryden and James Mangan}

I suppose Dryden does not appeal greatly to us today-but "Alexander's Feast" is a splendid thing, and I recall a song, "Sylvia the fair in the bloom of fifteen," which is even more perfectly versified.

Mangan's "Dark Rosaleen," however, has the most effective use of the refrain that I know. It has more passion and less exaltation than Poe's "For Annie."

As you are carrying the Oxford Book of English Verse around with you this summer, read after "Dark Rosaleen" another Mangan poem. 
Read "The Nameless One" with its most powerful and most touching of all endings:

Him grant a grave to, ye pitying noble, Deep in your bosoms: there let him dwell! $\mathrm{He}$, too, had tears for all souls in trouble, Here and in hell.

\section{Alexander Pope}

I progress rather slowly with Pope's Iliad which does not possess for me the charm of novelty. I find myself tremendously in sympathy with Pope in some things, though, and believe his version of Homer conveys a better idea of the original than any prose version can dothe prose versions I've seen are at their best biblical, and the Iliad is not that, whatever it is.

\section{Samuel Johnson and William Beckford}

The two prose things in the English language I should have hated most to miss are Vathek and Boswell's Life of Johnson. The only novel I've ever wished longer is Vathek. Richard Garnett has expressed my sentiments:

There are brighter stars in the literary firmament than Beckford, but few which can with equal propriety be likened to the evening star and the morning star. Nor is there, probably, any modern Oriental story except Vathek which might appear without disadvantage in the Arabian Nights with Aladdin on its right hand and Ali Baba on its left.

\section{William Wordsworth}

Did you ever read "The Sailor's Mother"? I never did before today, but thought it one of the finest examples of Wordsworth's success in giving great poetry in ordinary speech and from the stories of humble people. This poem, by the way, is an argument for reading Complete Poems. It does not appear in the Oxford nor in Arnold's splendid selection. I wonder if you have seen it. On a wintry road the poet meets a proud woman begging an alms:

"What is it," said I, "that you bear

Beneath the covert of your Cloak,

Protected from this cold damp air?"

She answered, soon as she the question heard, "A simple burthen, Sir, a little Singing-bird." 
And thus continuing, she said,

"I had a Son, who many a day

Sailed on the seas, but he is dead;

In Denmark he was cast away:

And I have traveled weary miles to see

If aught which he had owned might still remain for me.

"The bird and cage they both were his:

'Twas my Son's bird; and neat and trim

He kept it: many voyages

The singing-bird had gone with him;

When last he sailed, he left the bird behind;

From bodings, as might be, that hung upon his mind.

"He to a fellow-lodger's care

Had left it, to be watched and fed,

And pipe its song in safety;-there

I found it when my son was dead;

And now, God help me for my little wit!

I bear it with me, Sir;-he took so much delight in it."

The close is like a stanza in Spenser's "Astrophel," extremely touching yet completely restrained:

That hearbe, of some, Starlight is cald by name, Of others Penthia, though not so well;

And thou, where ever thou doest finde the same, From this day forth do call it Astrophel;

And when so ever thou it up doest take, Do pluck it gently for that shepheards sake.

Wordsworth's "The Solitary Reaper" with its "Old unhappy, far-off things/ And battles long ago" has in a few lines the essence of poetry, of course. Even Keats's "Charmed casements, opening on the foam of perilous seas ..." has not quite the strange, sad, ultra-poetic quality of the Wordsworth, but no English poet has ever done the thing as well as Catullus.

\section{Walter Savage Landor}

Landor is a problem in a Romantic Period course, for as you know he lived an extremely long life-printed his first book, I think, before 1800 , and his last more than 60 years later. Never a popular poet, his 
even, high level of quality over all those years is amazing-and as the only English poet who was ever really Hellenistic in spirit I have a very deep interest in him. As "Rose Aylmer" was a favorite poem with Charles Lamb, however, I would plan to treat Landor along with that group. And just to bring him into view, I indite here:

\section{Verse}

Past ruin'd Ilion Helen lives,

Alcestis rises from the shades;

Verse calls them forth; 'tis verse that gives

Immortal youth to mortal maids.

Soon shall Oblivion's deepening veil

Hide all the peopled hills you see, The gay, the proud, while lovers hail

These many summers you and me.

\section{Kirke White}

1 have been reading the poems of Kirke White. Did you know that he added a stanza to Waller's "Go, Lovely Rose"?

Yet, though thou fade,

From thy dead leaves let fragrance rise;

And teach the maid

That Goodness Time's rude hand defies;

That Virtue lives when Beauty dies.

\section{Mother Goose and Imperfect Rhyme}

The secret of the charm of imperfect rhyme lies deep in our psychology. Is it not partly due to the occurrence of such apparently imperfect rhymes, as wander and gander, or substitutions for them where a word is obsolete? Poe and others have used such rhymes and the suggestion that they suggest the old times and so charm us has been made. But I think the charm lies deeper in old times known to people too unsophisticated to think of Chaucer or Spenser-the old times of our own childhood, and the one kind of poetry almost wholly enjoyment, since never made a task, the songs of Mother Goose.

\section{Byron and Swinburne}

Byron said, "All the innovations of Romanticism have been vastly 
overrated" because he himself was not eminently successful in romantic pieces. Don Juan is his greatest work. My admiration for The Deformed Transformed is rather for the passion, and the insight it gives of Byron's school than for its other qualities, and I would hardly go so far as to call it his best work. It is his most revealing. Swinburne has a song and sings it well, but he takes thousands of lines to say what Byron says in four:

For the sword outwears its sheath, And the soul wears out the breast, And the heart must pause to breathe And love itself have rest.

\section{George Moore's "Pure Poetry"}

Of course Moore's theories are interesting, though they will not always hold water. The result with Shelley is, as you see, the proof of this. I cannot accept "The Cloud" as a fine example of Shelley's "pure poetry." No one can limit poetry by any rules, and it is better to fit ourselves to appreciate many styles than to say "this is a worthless style because I do not like it." Of course the like or dislike of a very sensitive person is of great importance. I am glad to see he chooses "Meg Merrilies" from Keats. ${ }^{3}$ When I first read Keats through, I said I

3 The text of "Meg Merrilies" follows:

Old Meg she was a gipsy; And lived upon the moors;

Her bed it was the brown heath turf, And her house was out of doors.

Her apples were swart blackberries, Her currants, pods o' broom;

Her wine was dew of the wild white rose, Her book a church-yard tomb.

Her brothers were the craggy hills, Her sisters larchen trees;

Alone with her great family Sho lived as she did please.

No breakfast had she many a morn, No dinner many a noon,

And stead of supper, she would stare Full hard against the moon.

But every morn of woodbine fresh She made her garlanding, And every night, the dark glen yow She wove, and she would sing. 
considered it his best poem-that it was what Wordsworth should have been at his best.

Moore is a good critic. I particularly agree with his statement that great artists "by one work may light up an abyss of soul," but there must be this magical and unique word. Shakespeare gives us the word, Balzac sometimes, Turgenev gives it with miraculous certainty. I feel I find, if not the word, felicitious passages in Flecker in such lines from Hassan as

Shower down thy love, $\mathrm{O}$ burning bright, for one night or the other night

Will come the Gardener in white, and gathered flowers are dead, Yasmin.

\section{Emily Dickinson and Blake}

Emily is a fine poet for the intelligentsia, not only for her innovations in prosody, but for her attempts to pierce through to the unknowable. She did not, however, like Blake, have a profound spiritual doctrine to pronounce, nor could she produce such a piece as that amazing poem, "The Everlasting Gospel," where the run-on couplets seem to rush with the force of a steady river. Queer in many ways, Blake was a very great man in his humanity. In "The Divine Image" you recall the lines:

Where Mercy, Love and Pity dwell

There God is dwelling too.

\section{Maria Brooks}

Some day there will be an edition of Maria Brooks' writings-they are "honorable to literature" as Disraeli said of something he wrote. In

And with her fingers, old and brown,

She plaited mats of rushes,

And gave them to the cottagers

She met among the bushes.

Old Meg was brave as Margaret Queen,

And tall as Amazon;

An old red blanket cloak she wore, A chip-hat had she on.

God rest her aged bones somewhere! She died full long agonel 
her epic, Zophiel, there is a Song. These are lines which Charles Lamb thought "so fine no woman could have written them," the lines Southey thought worthy of Sappho herself. Written in Cuba, the poem seems to hold in it the fire of the blazing stars of that sky-to feel the full effect one must imagine an evening balmy as a few nights are with us in June. Then it seems the perfect expression of a lonely heart-unquestioning in its passionate devotion; the words of the singer gradually increasing in vigor from the description of the first lines to the utter abandonment, at the end, of everything else in a consuming flame of unselfish love.

Day, in melting purple dying, Blossoms, all around us sighing, Fragrance, from the lilies straying, Zephyr, with my ringlets playing,

Yet but waken my distress:

I am sick of loneliness.

Absent still? Ahl come and bless mel

Let these eyes again caress thee,

Once, in caution, I could fly thee;

In a look if death there be,

Come, and I will gaze on thee!

\section{Francis Thompson and Richard Crashow}

The prose of Francis Thompson is too little spoken of. He is perhaps too religious to be thought of by the casual reader as keenly critical. Actually he is most gifted in appreciation of the rare qualities of the highest lyricism, and of ecstatic religious feeling. When he finds these two qualities combined in a poet, as they are in the matchless Richard Crashaw, he shines and understands what so many modern critics overlook-the really outstanding position of Crashaw among the metaphysical poets, rightly rating him above Donne for lyric quality, and as an ancestor, in a way, of Shelley. The criticism of Spenser is right, too-of course the Four Hymns are worth half of The Faerie Queene, or maybe all of it, and Spenser's true feeling was for the lyric.

Thompson occasionally is absurd enough, as note his weak attempt to prove the greater spirituality of Christian over Greek and Latin poetry. One hears constantly of Thompson's work on Shelley, keen and lovely and enthusiastic. But it is only superior in length, not in quality, to much of his minor criticism of poetry. The comments of such a 
man on any poetry, even forgotten poetry, must be precious in the eyes not only of the religious mind, Catholic or Protestant, but of everyone who really cares for pure poetry-which is a holy thing.

\section{Poets Loved Abroad}

Byron, Poe, and Whitman-a strange group-all perhaps more loved abroad than at home-have, I think, the greatest influence of poets of the modern language on the readers of other lands today.

Some of us, as we read the two earlier of these poets, are, like the Duc de l'Omelette in Poe's story, who "could not help imagining that the glorious, the voluptuous, the never-dying melodies which pervaded that hall, as they passed and filtered and transmuted through the alchemy of the enchanted window-panes, were the wailings and howlings of the hopeless and the damnedl" Yet this transformation of the terrible into the beautiful, this turning of "infernal agonies," as Sir Philip Sidney says, "into a beauty divine," if it be not, as Poe sometimes thought, the chief function of the poet, is certainly one of his functions. And if the beauty be indeed divine, who shall ask from what soil the lily sprang, if it is "the plant and flower of light."

\section{Robert Brouning}

Do you know Paracelsus? It is a strange, difficult, compact blank verse affair-a series of mental thinkings aloud, but no mean accomplishment in revealing the soul-struggles of the artist, the genius, the intellectual. To be a thing for its own sake, to despise even praise when it is bestowed upon the by-product of the great endeavor-that is the theme. There is, of course, also a good deal of portrayal of the historical strange being whom Browning used to center his drama of the soul. I wonder at the size of Browning's audiences, or is it that there are many whose souls are greater than their mind's abilities, and who hail in him the sturdy and unconquered soul to whom their own is kin?

Browning, when a boy, used to visit a certain toad that would come to him and let him stroke its head-Browning commented on the beauty and look of affection in his eyes. And when he was old he wrote a poem about that, "White Witchcraft." Does it not seem this one incident-ex pede Herculem-reveals the man, his interest in all things, even the ugliest, where love shines through?

\section{Edward Coote Pinkney}

My work on Pinkney is the thing most on my mind now-minor 
figure as he is, there is a certain charm about some of his lines that enchants me-for instance where Ponce de Leon, dreaming of success in his search for the Fountain of Youth, says to his love that his greatest joy will lie in the thought that "The sun has kissed no face/Forever fair as thine!" I have quoted to you before the glorious "Look out upon the stars my Love/And shame them with thine eyes."

Poe was a gentleman because he was brought up to be one. Pinkney was a gentleman because his family for generations had been-he was one of the few Americans with noble blood. Poe had weaknesses. Pinkney had none. He was rather a terrible person, but his faults were of strength, not of weakness. My real sympathies are with him, more than with Poe, and my heart beats to his measure in such lines as

$$
\begin{aligned}
& \text { On, on-my heart is here, } \\
& \text { My sword is at my side. }
\end{aligned}
$$

\section{Edgar Allan Poe}

The faults of the man and the mistakes of his life have been discussed and explained or condemned over and over again. They do not necessarily affect in any way our delight in the poems or our estimate of their worth. Poe's object was to obtain release from the sorrows of life through his song, and he did not regard his personal misfortunes as something that he must take with him into the realm of the imagination. The poetry has long outlived the errors of his mortality.

Nevertheless the reactions of readers to Poe's poetry are often dependent on their knowledge and opinion of the man himself. Some persons have always found him a most appealing figure. He was unfortunate and they like to weep over him; and they try to sentimentalize him, in some cases to deny his faults as the calumnies of his enemies. Others have a thorough dislike for the man which they extend to his verse. Every vivid personality annoys some people and selfconscious genius is not easy to get along with when accompanied by a desire to rebuke pretentious claimants to like power, and by a gift for saying bitingly true things.

If you dislike Poe because you are a cheerful soul and, like Emerson, can see nothing in "The Raven," are not interested in the dark side of the imagination, or are inexperienced in romantic discontent, you are out of sympathy with Poe's art and may as well lay his books down since, after all, every man to his own taste. If you dislike him because after a thorough consideration you find him not the kind of man you 
My dear mstricketion, Loudon, Guly 26, 927.

Here Pam, attast, in Condon - near the Britest Museim - and inst come from viniting it for the. finst time. The Coim Deft. peopple traated me very kindly of have my readeis wicted ztc. OK.

Naturally 9 wandered for hours in the gellerieo and after gaging at hundreds of memorials of bastenity' and savagery, came at last to the galleries of Graek sculpture. Thers is rest for the heart beyoud beluf: - that the human mind, cafable of a million vagaries should so disipline tolf to order, and to joy in the midat of formless terror, is a trimple. at once signal and befond all else encouraging. And strangely snough it was not the Elgin marblas, plundared from the broken Tarthenon, whide most impressed me, but the Caryatid from the Erechthenm - no cant or photograph consrys the sublime dignity the complete pentray al of the diomity in human form - the siffrienty of the grace and beanty of that form over all slse whid we may know in its simplicaty and complenty" wrinders 9 single that out - perfaction tho brotem, and marred - humanity; Greek, curluged, reasoning, healthy, standing with tresses and garments blown by the windo of time - the diomity in it lobliest aspect, manifested in than! She is pictured in many places soiere gor. $u n$ look at her, and was not new to me, Tho' the fall siginfieana tvis! Gordmight, deas, and love from tom.

A letter from Thomas Ollive Mabbott to Maureen Cobb, dated July 26, 1927, concerning Mr. Mabbott's first visit to the British Museum. 
can sympathize with, again, do not bother with his books. But if you are out of sympathy because you think that he wrote while drunk, or beat his wife, or was cruel to his cat, or is too much slobbered over by certain writers who have printed their views about him, then give him a chance to appear through his poems, as he really was, with a little of Time and Space under the forms of America and the years 1827-1849 rubbed away by the more lasting qualities of his art.

\title{
Favorite Poe Poem
}

You ask what is my favorite Poe poem. Such a question always brings an emotional answer from me, and my choice is "Eldorado," though I do not rank it first among his poems. It is Poe's comment on the California gold rush of 1849 , where many who sought treasure found death. The attitude of facing life boldly is something more often thought of as Browning's than Poe's, but Poe's most admirable quality was his gallant devotion to literature "in sunshine and in shadow." That last stanza is as heartening as anything I know:

\author{
Over the Mountains \\ Of the Moon, \\ Down the valley of the Shadow, \\ "Ride, boldly ride," \\ The shade replied,- \\ If you seek for Eldorado."
}

The poem was obviously inspired by something Poe read in a chapter of one of his favorite books, Isaac D'Israeli's Curiosities of Literature, about the harmless madmen, familiar to us from King Lear, who wandered about England begging, and were called "Tom o' Bedlams." D'Israeli quotes a Tom-o-Bedlam song. The seventh stanza reads

With a heart of furious fancies,

Whereof I am commander,

With a burning spear,

And a horse of air,

To the wilderness I wander;

With a knight of dreams and shadows,

I summoned am to tourney;

Ten leagues beyond

This wild world's end;

Methinks it is no journey! 
D'Israeli adds, "The last stanza of this Bedlam song contains the seeds of exquisite romance; a stanza worth many an admired poem."

\section{Walt Whitman}

Of all the poets of the nineteenth century, Whitman has the most to say to the twentieth. If the American people could get Whitman into their consciousness and know Leaves of Grass, we'd see a greater nation.

Whitman himself developed slowly, and for all his sympathy with the normal, need not be supposed a more average person than Dante, or Goethe, or Shelley, or Milton, or Wordsworth, or Dr. Johnson, or Byron, or Shakespeare. The evidence for a homosexual tendency in Walt is of the same nature as that for one in Shakespeare-and however one may dislike the tendency, the problem only incidentally concerns the reader of Leaves of Grass.

He says indifferently and alike How are you, Friend? to the President at his levee.

And he says Good-day, my brother, to Cudge that hoes in the sugar-field,

And both understand and know that his speech is right.

Many things shock an immodest person that do not shock a modest person. Whitman shocked some people, so does God.

Most of the followers of Whitman have been repelled by him at first, but one must lay aside all prejudices and read the Leaves of Grass-at any rate the first hundred pages, and in the first edition if possible-before condemning it on the basis of personal vagaries of the author. One needs neither to defend or commend him to those who read him. But one rather regrets anything which may prevent people reading an author who gives many of us who seek God a conception neither at war with science, nor negative of all reality. In a word Walt combines the virtues of stoicism with an enthusiastic acceptance of life. He himself, "of many a smutched deed reminiscent," found life worthwhile for the sake of those he loved. He struck one of his finest notes in the last stanza of "Dirge for Two Veterans":

The moon gives you light

And the bugle and the drums give you music, And my heart, $\mathrm{O}$ my soldiers, my veterans, My heart gives you love. 


\section{Sidney Lanier}

Lanier's "Sunrise" has in it everything Browning and Shelley and Swinburne tried to do-and sometimes did. I pick for your favorite the passage where, while the live-oaks, the marsh, and the sea lie waiting, he goes, before the dawn, in the darkness of night, to his beloved trees to hide in their "gospeling glooms," to listen to their leaves:

Sift down tremors of sweet-within-sweet

That advise me of more than they bring,-repeat

Me the woods-smell that swiftly but now brought breath

From the heaven-side bank of the river of death,-

Teach me the terms of silence,--preach me

The passion of patience.

I share the ecstasy, but I myself wait for that great, Olympian-leisured entrance, "Good-morrow, Lord Sun!"

\section{James Elroy Flecker and A. E. Housman}

I have just finished poor Flecker's poems and now we must read Hassan. There is nothing else quite up to The Golden Journey to Samarkand," I think, but there is a richness in various places that pleases me. His war poetry is like the other crowd's-only Housman could do that with dignity, passion, and "unreason" enough. Remember his

\section{Epitaph on an Army of Mercenaries}

These, in the day when heaven was falling,

The hour when earth's foundations fled, Followed their mercenary calling

And took their wages and are dead.

Their shoulders held the sky suspended;

They stood, and earth's foundations stay;

What God abandoned, these defended,

And saved the sum of things for pay.

\section{Old Songs}

Willa Cather tells of the sorrow of an old song. I have just heard Hawaiians singing "Lay my head beneath a rose." There is here, in its simplest form, a cadence which is in the deepest way the soul of Mozart and Poe-the most sorrowful cadence in the world. 